\title{
CORRESPONDENCE
}

\section{ISOTOPIC AGES OF LATE CALEDONIAN GRANITIC INTRUSIONS IN THE BRITISH ISLES}

SiR,-Brown, Miller \& Grasty (1968, p. 267-8) suggested that the intrusive styles of Caledonian granitic complexes in the Scottish Highlands are governed by depth of cover and temperature of country rocks at the time of emplacement. According to their hypothesis the earlier granites lack distinct thermal aureoles and are often surrounded by marginal zones of injection and migmatization, characters attributed by them to intrusion at greater depth in warmer rocks. Consideration of the information already available for a number of granitic complexes in the Northern Grampian Highlands shows that this view is too simplified.

The Strathspey, Dalchully, Corrieyairack, Allt Crom, Strathdearn, and Grantown granitic complexes are all sub-concordant with the regional foliation and show a number of structural similarities but have ages varying from 430 m.y. (Strathspey) to 393 m.y. (Dalchully). They are predominantly granodioritic, contain large numbers of enclaves of metasediment and are surrounded by zones in which large numbers of minor apophyses penetrate the country rock (Smith, 1965, 1968 ; Anderson, 1956, p. 21-2 ; Mackenzie, 1957, 1958). The Strathspey and Grantown complexes show evidence of plastic and brittle deformation of the country rocks (Smith, 1965, p. 462; 1968 ; Mackenzie, 1958, p. 68-9, Text-fig. 1) but there is no evidence of more than one phase of intrusion.

Four of the complexes have been radiometrically dated ; the Strathspey Complex (430 m.y.), the Dalchully granite (393 m.y.), the Allt Crom granite (404 m.y.) and the Strathdearn Granite (406 m.y.). All lie within metamorphic rocks which yield radiometric ages in the range of 420-430 m.y. (Miller \& Brown, 1965, Table 2a). The Strathspey Complex, Dalchully granite and Strathdearn granite are intruded into a zone of regional migmatization but the Allt Crom granite lies outside its limits (Johnstone, 1966, Fig. 9).

Thus, within a relatively small area, three structurally similar granites (Strathspey, Dalchully and Strathdearn) give radiometric ages spreading over nearly 40 m.y., and another structurally similar granite intruded outside the zone of migmatization gives an intermediate age (Allt Crom). In the same general area the Strath Ossian Granite, which is notably different structurally from the previously described complexes in that it is discordant to the strike, is dated at 414 m.y. (Harper, 1967, Table 2).

None of these granites shows a distinct thermal aureole, they intrude both migmatized and unmigmatized metasediments and are commonly surrounded by a zone of minor apophyses. No systematic variation in environment or structure with radiometric age can be demonstrated. This evidence suggests that the intrusive style of a granite complex is not connected with depth of emplacement and temperature of country rocks alone, but is influenced by other variables.

If all of the granites described above, which show similar intrusive style, were intruded at the same depth and time then their spread in radiometric ages might be accounted for as the result of differential uplift of the various bodies. The older bodies may have been uplifted first, and hence cooled earlier to the threshold temperatures of retention of radiogenic argon. However, all of these granites are intruded in a relatively small area and there is no evidence to support the idea that they have been uplifted separately. In the case of the Strathspey Complex and the Dalchully granite which are only about 3 kilometres apart in the field, and which occupy very similar structural and metamorphic environments, differential uplift seems a most unlikely explanation of the difference in radiometric ages (approx. 40 m.y.). It is suggested that, in spite of their structural similarities, these granites represent a sequence of intrusions emplaced at intervals over a period of at least $40 \mathrm{~m} . \mathrm{y}$.

One variable which may influence the structural style of a granitic complex is the condition of the magma at the time of intrusion. In the case of the Strathspey Complex there is petrographic evidence that the magma was nearly fully crystalline before int rusion was completed.

Further support for the criticism of the correlation of intrusive style with radiometric 
age may be found in the comparison of the Rogart Igneous Complex ( 424 m.y., Brown, Miller \& Grasty, 1968, Table 2) with the Strathspey Complex (430 m.y. Miller \& Brown, 1965, Table $2 d$.) Both complexes show evidence of plastic deformation and brittle deformation of the country rocks during intrusion. In the Rogart Complex these deformations may be correlated with the intrusion of a granodiorite magma followed by the intrusion of a biotite granite magma (Soper, 1963, p. 473) whilst in the Strathspey Complex only one intrusive phase is noted. Such an obvious difference in the intrusive history in two otherwise similar complexes can scarcely go unremarked. Although there is no convincing radiometric evidence for the differentiation in time of the various phases of multiple intrusions (Brown, Miller \& Grasty, 1968, p. 275) there must be some time interval between the two phases of intrusion noted in the Rogart Complex, to allow for differentiation and perhaps a change in the country rock conditions. It is difficult to even guess at the length of this interval particularly in complexes like Rogart where the radiometric age of the country rocks is more or less coincident with that of the granite. In such cases it is entirely possible that the granites were emplaced very much earlier than is indicated by the radiometric ages which may represent the time at which all of the rocks of the area cooled sufficiently to retain radiogenic argon.

\section{REFERENCES}

ANDerson, J. G. C. 1956. The Moinian and Dalradian rocks between Glen Roy and the Monadhliath Mountains. Trans.R. Soc. Edinb., 63, 15-36.

Brown, P. E., Miller, J. A. \& Grasty, R. L. 1968. Isotopic ages of Late Caledonian granitic intrusions of the British Isles. Proc. Yorks. geol. Soc., 36, 251-76.

HARPER, C. T. 1967. The geological interpretation of potassium-agron ages of metamorphic rocks from the Scottish Caledonides. Scott. J. Geol., 3, 46-66.

Johnstone, G. S. 1966. The Grampian Highlands. Brit. reg. Geol., Geol. Surv. U.K., H.M.S.O., London.

MACKENZIE, D. H. 1957. On the relationship between migmatisation and structure in mid-Strathspey. Geol. Mag., 94, 177-86.

1958. The structure of the Grantown Granite Complex, Moray-shire. Geol. Mag., $95,57-70$.

Miller, J. A. \& Brown, P. E. 1965. Potassium-Argon age studies in Scotland. Geol. Mag., 102, 106-34.

SOPER, N. J. 1963. The structure of the Rogart igneous complex. Q. Jl geol. Soc. Lond., $119,445-78$.

Smith, T. E. 1965. Potassium-Argon age studies in Scotland. Geol. Mag., 102, 462-3. 1968. The geological interpretation of Potassium-Argon ages of metamorphic rocks from the Scottish Caledonides. Scott. J. Geol., 4, 68-84.

Department of Geology,

UNIVERSITY OF THE WEST INDIES,

T. E. SмIтн.

Mona, KingSTON 7, JAMAICA.

26th July, 1968.

SiR, - We look forward to the publication of any geological information which may facilitate interpreting the radiometric ages of the Caledonian granites.

Two relevant points in the paper referred to by Dr. Smith (Brown, Miller \& Grasty, 1968) are :-

1. The K-Ar ages of some granites are similar to those of the surrounding schists which form the regional country rocks, so that the schists and granites evidently became closed systems together.

2. The majority of the Caledonian granites have K-Ar ages significantly younger than the regional schists and were intruded into rocks which were closed systems to argon.

Dr. Smith observes that in the Northern Grampian Highlands granites were intruded over a period of at least 40 m.y. while maintaining the same structural characteristics and lack of thermal effects. For the difference in granite ages to be detectable over this 
comparatively small area the temperature of the regional country rocks must have been such that they were a closed system to argon (with the possible exception of the Strath Spey granite for which the K-Ar ages approximate to those of the country rocks). This is indicative of intrusion into essentially " cool " country rocks and gives added interest to the geological interpretation of the structural and metamorphic characteristics of the granites.

May we reiterate our comment in the paper that much radiometric and geological information is still necessary to clarify the interpretation of the Caledonian age pattern.
DEPARTMENT OF GEODESY AND GEOPHYSICS,
J. A. Miller.
MADINGLEY ROAD,
P. E. BROWN.

CAMBRIDGE.

17th September, 1968.

\section{TRACE FOSSILS FROM NAMURIAN SANDSTONE, YORKSHIRE}

SIR,-In view of R. W. Sheldon's record of probable gastropod tracks from the Kinderscoutian Stage $\left(\mathrm{R}_{1}\right)$ of the Central Pennines (Geol. Mag., 105 (4), 365-6) it is pertinent to note the occurrence of similar trace fossils in the same region but at a higher stratigraphical horizon.

At the abandoned Tower Quarry, Cornholme (SD 707 231), some 3 kilometres north-west of Todmorden, Yorkshire, trace fossils of the Repichnia group are common on stratification surfaces within the Hazel Greave Grit. This Namurian sandstone of Marsdenian $\left(\mathrm{R}_{2}\right)$ age is hereabouts micaceous and occasionally carbonaceous. Smooth sinuous tracks between 7 and $14 \mathrm{~mm}$ wide with the well defined "gill-like" transverse structures similar to those on Sheldon's illustration (Plate 12) are attributed as Olivellites.

Department of Mining and Geology, I. A. and R. I. H. Williamson.

Mining and Technical College, WIGAN.

12th September, 1968

\section{REVIEWS}

Martin, P. S. \& Wright, H. E. Jr. (Eds.) 1967. Pleistocene Extinctions: The Search for a Cause. (Vol. 6 of Proc. VII Congress, International Association for Quaternary Research.) $x+453$ p., figs. Yale University Press, New Haven and London. Price 55 12s. 6 d.

The apparently sudden extinction of many groups of animals in the later Pleistocene, in many parts of the world, has been a subject for speculation among scientists for years and the aims of this INQUA conference were to canalize some of the many widely differing theories. With many diverse disciplines contributing to this subject, a wide if not exhaustive coverage of many aspects relating to Pleistocene extinctions can be presented. As Paul Martin stresses in the preface, whatever else this volume may have contributed, the issues have been sharpened " and above all made more vulnerable to further testing". These words sum up the positive value of the book, that although it may have many shortcomings, and criticism can be levelled on many counts, nonetheless the stimulation to further thought and investigation must not be underestimated.

Inevitably, the accent throughout most of the book is on the problem as it affects North America, and this region is dealt with in much greater detail than any other area. 